\title{
Thermal Oxidative and Non-Oxidative Degradation Behaviour of Afuze Coal
}

\author{
Bemgba B. Nyakuma ${ }^{1 *}$ \\ ${ }^{1}$ Clean Coal Conversion and Utilisation Group, Research Initiative for Sustainable \\ Energy Technologies, North-Bank, Makurdi, Benue State, Nigeria. \\ *Corresponding Author Email: bbnyax1@gmail.com
}

\begin{abstract}
This study presents a preliminary analysis of the chemical and thermal fuel properties of Afuze (AFZ) coal extracted from coalfields in Owan East Local Government Area of Edo State, Nigeria. The chemical properties of AFZ were examined by combined scanning electron microscopy-energy dispersive X-ray (EDX), whereas the thermal properties were deduced by thermogravimetric analysis (TGA) under flash $\left(50{ }^{\circ} \mathrm{C} / \mathrm{min}\right.$ heating rate) oxidative (combustion) and non-oxidative (pyrolysis) conditions. The microstructure and morphology analysis of AFZ revealed has a compact structure comprising small-to-large, irregular shaped and exfoliated grains with a vitreous appearance typically ascribed to metal elements ( $\mathrm{Ti}$ and $\mathrm{Fe}$ ) kaolinite, quartz, and other clay minerals. Chemical analysis revealed carbon, oxygen, aluminium, silicon, sulphur, calcium, titanium, and iron in major and minor (trace) quantities. Thermal analysis under oxidative and non-oxidative conditions revealed degradation occurs in three stages, namely; drying or demineralisation, devolatilization or maceral degradation and the formation of char/coke or ash. Lastly, the findings showed that the temperature range for the oxidative thermal degradation process $\left(338.58-756.76^{\circ} \mathrm{C}\right)$ was higher than the non-oxidative process $\left(378.43-615.34{ }^{\circ} \mathrm{C}\right)$. This observation can be explained by the exothermic nature of the oxidative (combustion) process, which ensures greater heat supply required to thermally soften or degrade the maceral coal components. Overall, the oxidative process yielded the residual mass $(\mathrm{RM}=21.97 \%)$ and mass loss $(\mathrm{ML}=78.03 \%)$. The lower ML (49.03\%) but higher RM (50.97\%) observed during nonoxidative degradation of AFZ could be ascribed to the largely endothermic nature of the process.
\end{abstract}

Keywords: Thermogravimetry, Thermal Degradation, Behaviour, Afuze, Coal, Nigeria. 


\section{Introduction}

Coal is a carbon-rich, brown to black, and energy-dense sedimentary rock that is widely utilised for electricity, cement, and steel production worldwide (Reddy, 2013; Speight, 2012). Current estimates indicate that the consumption of coal accounts for over $60 \%$ of all global fossil fuels, which makes it the largest source of primary fossil fuel utilized for electric power generation (Sarwar et al., 2014; Nyakuma, 2015). Despite its high industrial value, there have been growing calls for the phase-out of coal due to its negative impacts on the environment (Heinrichs et al., 2017; Blondeel et al., 2020). Currently, it is estimated that coal accounts for over $40 \%$ of energyrelated $\mathrm{CO}_{2}$ emissions (Chu, 2009; OECD Working Paper, 2012), along with 8\% of the global greenhouse gas emissions from cement production (Kajaste and Hurme, 2016; Teh et al., 2017). According to analysts, the continued utilisation of coal and other fossil fuels could exacerbate global warming and climate change. Against this backdrop, coal is considered one of the low cost and most widely accessible sources of energy with the potential to address the perennial energy crises in most emerging economies.

Energy is critical to socio-economic growth and infrastructural development (McCauley et al., 2016; Rafique and Rehman, 2017). Therefore, global access to low cost and reliable energy is fundamental to prosperity in the modern era (Pearson, 2014; McHugh, 2017). It is estimated that almost half of the global population has limited or zero access to electricity, which is a major impediment to socio-economic growth and development. Hence, various nations with vast coal supplies aim to exploit these supplies for electric power generation. One example of an emerging economy with perennial energy challenges is Nigeria. In spite of Nigeria's vast human, energy and natural resources (such as coal, natural gas and petroleum), the nation suffers from significant energy scarcity. Therefore, numerous analysts have called for the utilisation of the Nigeria's vast coal reserves, estimated at over 2.75 billion tonnes, for the generation of electricity (Sambo, 2009; Ohimain, 2014; Chukwu et al., 2016).

However, the challenges of utilising coal for power generation in Nigeria have been largely ascribed to the lack of comprehensive data on the physicochemical, thermal, calorific, kinetic and thermodynamic properties of Nigerian coals (Nyakuma et al., 2019; Akinyemi et al., 2020a). Despite the nation's vast reserves and newer finds currently reported in the literature (Nyakuma, 2016; Nyakuma et al., 2017; Nyakuma, 2019; Nyakuma et al., 2020), there is limited information on the fuel characteristics of Nigerian coals, which is required for the process design, engineering 
economics, waste profile and environmental analyses of future coal-fired power plants in the country. Therefore, this study presents a preliminary analysis of the chemical and thermal fuel properties of Afuze (AFZ) coal. The research works on the AFZ coal sample, which was extracted from coalfields in Afuze located in Owan East Local Government Area of Edo State, Nigeria, are limited in the literature.

\section{Experimental}

\section{Chemical Analysis}

The chemical composition of Afuze (AFZ) coal was examined by combined scanning electron microscopy (SEM) and energy-dispersive X-ray (EDX) spectroscopy. For each test, the pulverised AFZ was evenly spray-coated on carbon epoxy tape placed on sample grain mounts to disperse the coal particles. Next, the samples and grain mounts were transferred to the sample chamber of the SEM (Model: JEOL, JSM IT-300, Germany) for analysis. Next, the sample was scanned using the SEM microscope and a selected region of the resulting micrograph was mapped using the point ID technique. Next, the metallic and non-metallic elements in AFZ coal were computed in weight per cent (wt. \%) based on charge balance using the EDX software (AZTEC Oxford Instruments, UK). A detailed description of the SEM/EDX analyser and its operating conditions are presented in the literature (Nyakuma et al., 2021).

\section{Thermal Analysis}

The thermal properties and degradation behaviour of AFZ coal were determined by thermogravimetric analysis (TGA). For each test, approximately $15 \mathrm{mg}$ of pulverised AFZ was weighed in an alumina crucible and transferred to a sample bucket of the TG analyser. To examine the thermal-oxidative and non-oxidative degradation behaviour of AFZ, the sample was heated under air and nitrogen gas, respectively, from room temperature (RT) to $900{ }^{\circ} \mathrm{C}$ under a nonisothermal heating program at $50{ }^{\circ} \mathrm{C} / \mathrm{min}$ heating rate at the flow rates of $100 \mathrm{~mL} / \mathrm{min}$. The objective was to examine the thermal behaviour and degradation mechanism of AFZ under flash combustion (oxidative in air) and pyrolysis (non-oxidative in nitrogen) conditions. In the end, the raw data was processed to determine the mass loss (ML, \%) and derivative of mass loss (DML, $\% / \mathrm{min}$ ), which were subsequently plotted against temperature $\left({ }^{\circ} \mathrm{C}\right.$ ) in Microsoft Excel (version 
2013) to obtain the thermogravimetric (TG) and derivative thermogravimetric (DTG) plots presented in Figures 2 and 3 respectively.

\section{Temperature Profile Analysis}

Based on the TG-DTG plots in Figures 2 and 3, the characteristic temperature profiles of the AFZ under oxidative and non-oxidative conditions were determined using the Shimadzu software (Workstation TA-60WS, Japan). This feature of the software allows users to examine the thermal properties of thermally degrading materials through analysis of the characteristic temperature profiles after TGA. In this study, the temperature profile characteristics (TPCs) derived from the TG plots for AFZ degradation were; ignition temperature (Ti), midpoint temperature (Tm), offset temperature (Tf), mass loss (ML, \%) and residual mass (RM, \%), whereas the maximum drying peak (Td) and peak decomposition temperature (Tx) were deduced from the DTG plots. A detailed description of the procedures and guidelines for determining the TPCs are outlined in the literature (Nyakuma et al., 2021).

\section{Results and Discussion}

\section{Chemical Analysis}

The composition of metallic and non-metallic elements in AFZ coal was determined by energy-dispersive X-ray (EDX) spectroscopy computed in weight per cent (wt. \%) based on charge balance. Figures 1 (a \& b) present the SEM micrograph (a) and EDX Spectra (b) of AFZ coal. As observed in Fig 1a the AFZ coal is characterised by the compact structure devoid of pores or crevices typically found on the surface of other coal. Likewise, the surface is made up of small to large, irregular shaped and exfoliated grains or particles that have a distinct vitreous appearance, which is typically ascribed to the presence of metal elements in the structure. However, the glossy sheen observed in the SEM micrographs is reportedly also due to clay minerals such as kaolinite, quartz, and other metallic minerals in the AFZ coal structure. The white coloured, rounded or exfoliated grains in the SEM image indicate the occurrence of quartz; whereas the irregularly shaped grains denote the presence of kaolinite along with Ti and Fe metal elements (Sengupta $e t$ al., 2008; Bortnikov et al., 2013). 

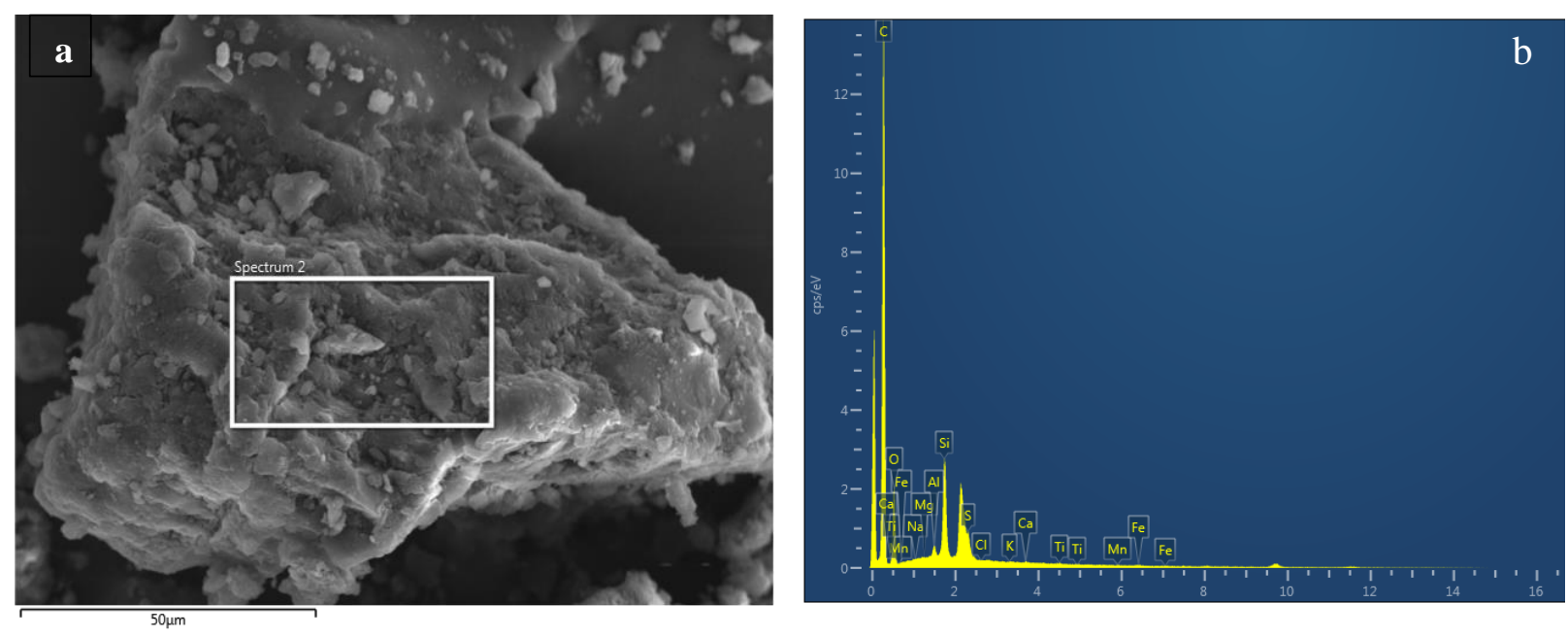

Figure 1: AFZ Coal SEM Micrograph (a) and EDX Spectra (b)

Next, the composition of metal and non-metallic elements present in the AFZ coal structure were then determined by charge balance as shown in Table 1. As observed, the chemical structure of AFZ is characterised by the elements; carbon, oxygen, aluminium, silicon, sulphur, calcium, titanium, and iron. Based on the results, the major elements (defined as composition > $5 \mathrm{wt}$. \%) in the AFZ coal structure are carbon and oxygen, which highlight the organic origins of the sample.

Table 1: EDX Chemical Composition of AFZ Coal

\begin{tabular}{ccc}
\hline Elements & Symbols & Composition (wt. \%) \\
\hline Carbon & $\mathrm{C}$ & 79.19 \\
Oxygen & $\mathrm{O}$ & 15.75 \\
Aluminium & $\mathrm{Al}$ & 0.34 \\
Silicon & $\mathrm{Si}$ & 3.18 \\
Sulphur & $\mathrm{S}$ & 1.17 \\
Calcium & $\mathrm{Ca}$ & 0.08 \\
Titanium & $\mathrm{Ti}$ & 0.09 \\
Iron & $\mathrm{Fe}$ & 0.20 \\
\hline
\end{tabular}

According to Xie et al. (2013), the maceral composition of coals is due to the contributions of lignin, cellulose, resins, spores and other polymeric organic materials derived from algae, fungi, and plants residues. In contrast, the composition of the minor elements (defined as composition < 
5 wt. \%) detected includes; silicon, sulphur, aluminium, iron, titanium, and calcium. The detection of silicon in the EDX analysis confirms the presence of quartz $\left(\mathrm{SiO}_{2}\right)$, which is considered one of the most abundant minerals in the earth's crust (Bi et al., 2021; Kim et al., 2018). The occurrence of sulphur and iron may be due to $\mathrm{FeS}_{2}$ (iron sulphide), whereas calcium may be due to $\mathrm{CaSiO}_{3}$ (calcium ino-silicate mineral or Wollastonite). Overall, the presence of metallic and non-metallic elements are crucial to the assessment of the origins (e.g. petrographic source rock characteristics and depositional settings) (Ayinla et al., 2017a; Ayinla et al., 2017b; Ogala, 2011; Ogala, 2012; Ogala et al., 2012), properties (e.g. physicochemical, geochemical, thermal degradation) (Nyakuma et al., 2018; Nyakuma and Jauro, 2016a; Ogala, 2018), and potential applications (e.g. hydrocarbon generation potential) of coal (Akinyemi et al., 2021; Akinyemi et al., 2020b).

\section{Thermal Analysis}

Figures 2 and 3 present the TG and DTG plots for the thermal-oxidative (combustion) and non-oxidative (pyrolysis) degradation AFZ under flash conditions. The plots showed that the increase in temperature from RT to $900{ }^{\circ} \mathrm{C}$ resulting in significant mass loss during TGA. The loss of mass of AFZ could be ascribed to the thermal degradation of the maceral components (namely; vitrinite, inertinite, and liptinite) of the coal sample. The composition of vitrinites, liptinites, and inertinites typically range from $50 \%$ to $90 \%, 5 \%-10 \%$, and $50 \%-70 \%$ based on source, rank, and classification of the coals (Speight, 2012; Nyakuma et al., 2021). Therefore, the mass loss of AFZ could be attributed to the thermal degradation of the maceral, lignitic and cellulosic plant materials (or organic fractions) or components present in the coal structure (Hayatsu et al., 1986; Košina and Heppner, 1984; Landais et al., 1989; Wu et al., 2017).

Similarly, the DTG plots showed that temperature affected the thermal degradation of AFZ during TGA. As observed, the process resulted in various endothermic peaks that occurred in the temperature ranges from $\mathrm{RT}-200^{\circ} \mathrm{C}, 200^{\circ} \mathrm{C}-600^{\circ} \mathrm{C}$, and $600{ }^{\circ} \mathrm{C}-900{ }^{\circ} \mathrm{C}$. The findings indicate the process of AFZ degradation occurred in three (3) stages, which is similar to the findings reported in the literature for various ranks of coal (Nyakuma et al., 2016; Akinyemi et al., 2020b; Nyakuma and Jauro, 2016b). The mass loss in stage I $\left(\mathrm{RT}-200^{\circ} \mathrm{C}\right)$ could be ascribed to the loss of surface-bound moisture and mineral hydrates in the coal structure (Sarwar et al., 2014), whereas stage II $\left(200{ }^{\circ} \mathrm{C}-600{ }^{\circ} \mathrm{C}\right)$ could be due to the degradation of the coal macerals (Sun et al., 2003; Zhao et al., 2011). According to Sun et al. (2003) and Zhao et al. (2011), the reactivity of the 
macerals particularly inertinite and vitrinite play crucial roles in determining the yield and composition of the thermal degradation products. Lastly, stage III $\left(600{ }^{\circ} \mathrm{C}-900{ }^{\circ} \mathrm{C}\right)$ may be due to the formation of char/coke or ash during the non-oxidative or oxidative degradation of AFZ, respectively.

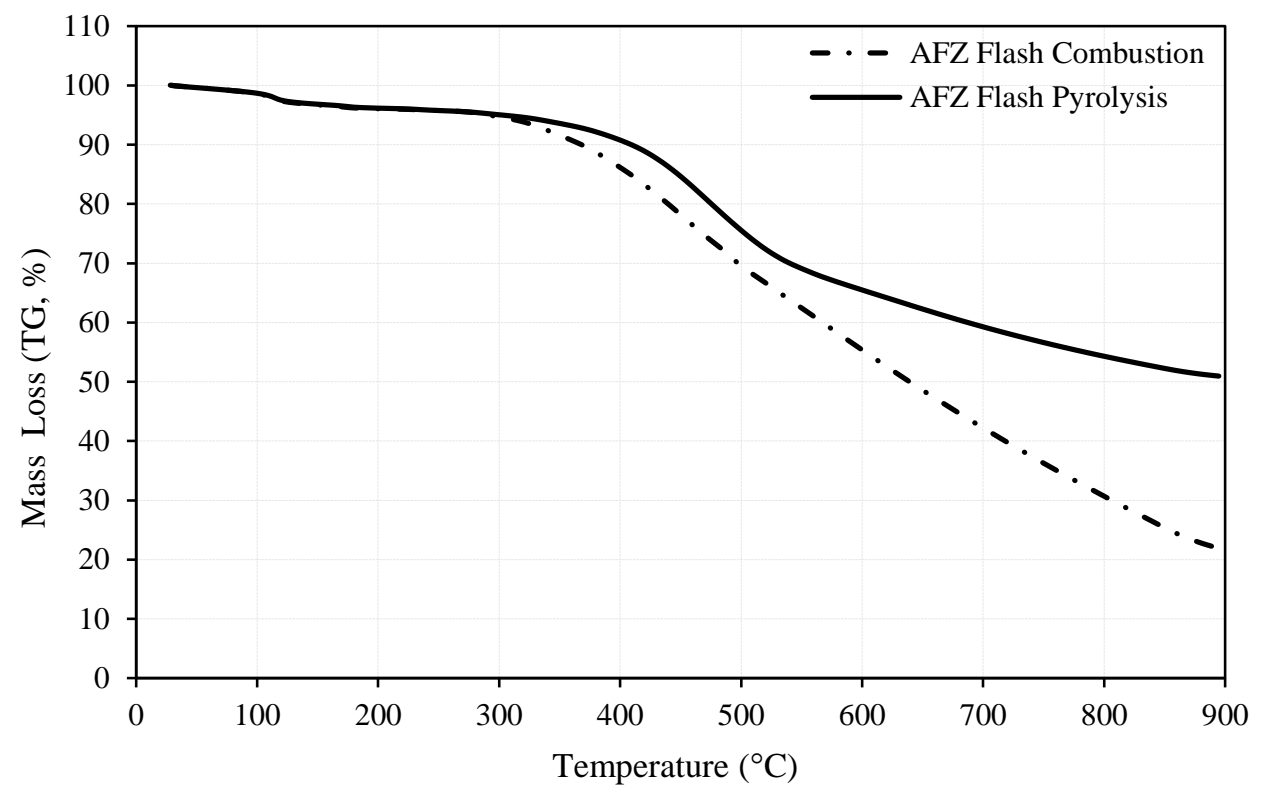

Figure 2: TG plots for thermo-oxidative and non-oxidative degradation of AFZ

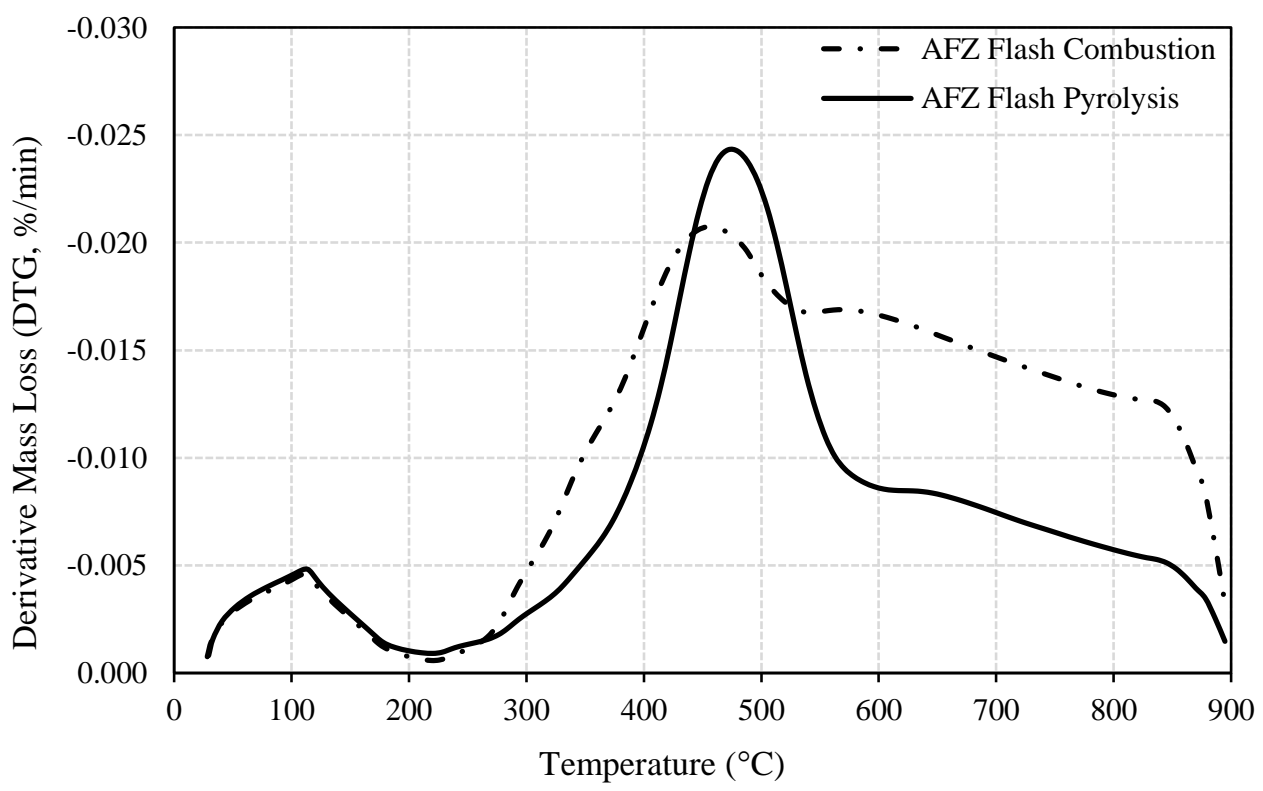

Figure 3: DTG plots for thermo-oxidative and non-oxidative degradation of AFZ 


\section{Temperature Profile Analysis}

The thermal degradation behaviour and reactivity of AFZ were further examined by analysing the temperature profile characteristics (TPCs) for the thermal-oxidative (combustion) and non-oxidative (pyrolysis) degradation of AFZ under flash conditions. In this study, the TPCs determined from the TG plots for AFZ degradation were; ignition temperature (Ti), midpoint temperature (Tm), offset temperature (Tf), mass loss (ML, \%) and residual mass (RM, \%). Table 2 shows the TPCs determined from the TG plots in Figure 2.

Table 2: TPCs for AFZ degradations based on TG Plots

\begin{tabular}{lccc}
\hline $\begin{array}{l}\text { Temperature Profile } \\
\text { Characteristics }(\text { TPC) }\end{array}$ & $\begin{array}{c}\text { Symbol, } \\
\text { Units }\end{array}$ & $\begin{array}{c}\text { Non-oxidative } \\
\text { (Pyrolysis) }\end{array}$ & $\begin{array}{c}\text { Oxidative } \\
\text { (Combustion) }\end{array}$ \\
\hline Ignition Temperature & $\mathbf{T i},{ }^{\circ} \mathbf{C}$ & 378.43 & 338.58 \\
Midpoint Temperature & Tm, ${ }^{\circ} \mathbf{C}$ & 488.13 & 539.62 \\
Offset Temperature & $\mathbf{T f}^{\circ} \mathbf{C}$ & 615.34 & 756.76 \\
Mass Loss & $\mathbf{M L}, \boldsymbol{\%}$ & 49.03 & 78.03 \\
Residual Mass & $\mathbf{R M}, \boldsymbol{\%}$ & 50.97 & 21.97 \\
\hline
\end{tabular}

Based on Table 2, the non-oxidative (pyrolysis) degradation of AFZ occurred from 378.43 ${ }^{\circ} \mathrm{C}$ to $615.34{ }^{\circ} \mathrm{C}$, whereas oxidative (combustion) was between $338.58{ }^{\circ} \mathrm{C}$ and $756.76{ }^{\circ} \mathrm{C}$. The findings indicate that the oxidative process exhibited a lower Ti but higher Tf when compared to the non-oxidative process. Intrinsically, the range of the degradation temperature range for the oxidative process was higher, which resulted in a higher mass loss (ML $=78.03 \%)$ and lower residual mass $(\mathrm{RM}=21.97 \%)$ compared to the non-oxidative process. This could be explained by the exothermic nature of the oxidative (combustion) process, which has adequately greater heat required to thermally soften or degrade the chemical bonds of the maceral components in the coal structure. Likewise, the lower ML but higher RM observed during non-oxidative degradation of AFZ could be ascribed to the largely endothermic nature of the process, as reported in the literature (Agroskin et al., 1972; Hanrot et al., 1994). Similar findings were reported for various ranks of coals from Nigeria (Sonibare et al., 2005; Chukwu et al., 2016; Nyakuma et al., 2021).

Table 3 shows the maximum drying peak (Td) and peak decomposition temperature (Tx) deduced from the DTG plots in Figure 3. Except for DPR, all the TPCs (Td, Tx, and PDR) for the non-oxidative (pyrolysis) are greater than observed for the oxidative (combustion) process. 
Table 3: TPCs for AFZ degradations based on DTG Plots

\begin{tabular}{lccc}
\hline $\begin{array}{l}\text { Temperature Profile } \\
\text { Characteristics (TPC) }\end{array}$ & $\begin{array}{c}\text { Symbol, } \\
\text { Units }\end{array}$ & $\begin{array}{c}\text { Non-oxidative } \\
\text { (Pyrolysis) }\end{array}$ & $\begin{array}{c}\text { Oxidative } \\
\text { (Combustion) }\end{array}$ \\
\hline Maximum Drying Peak & Td, ${ }^{\circ} \mathbf{C}$ & 29.37 & 28.21 \\
Drying Peak Rate & DPR, $\% / \mathbf{m i n}$ & 0.31 & 0.32 \\
Peak Decomposition Temperature & $\mathbf{T x},{ }^{\circ} \mathbf{C}$ & 471.77 & 453.97 \\
Peak Decomposition Rate & $\mathbf{P D R}, \boldsymbol{\%} / \mathbf{m i n}$ & 6.88 & 4.52 \\
\hline
\end{tabular}

\section{Conclusion}

The study examined the chemical and thermal properties of Afuze coal. The chemical analysis revealed that AFZ contains major and minor (trace) elements comprised of carbon, oxygen, aluminium, silicon, sulphur, calcium, titanium, and iron. The major elements (defined as composition > 5 wt. \%) are carbon and oxygen, whereas the minor elements (defined as composition < 5 wt. \%) detected were; silicon, sulphur, aluminium, iron, titanium, and calcium. The thermal analysis of AFZ under oxidative and non-oxidative conditions under flash $\left(50{ }^{\circ} \mathrm{C} / \mathrm{min}\right.$ heating rate) conditions provided insights into the thermal behaviour and degradation mechanism of AFZ. Furthermore, the findings revealed that the thermal degradation of AFZ occurred in three stages due to drying (loss of moisture) or demineralisation, devolatilisation or maceral degradation and the formation of char/coke or ash during the processes. Lastly, the findings showed that the degradation temperature range for the oxidative process was higher when compared to the nonoxidative process. Overall, the oxidative process yielded lower residual mass $(\mathrm{RM}=21.97 \%)$ but higher mass loss $(\mathrm{ML}=78.03 \%)$.

\section{Acknowledgement}

The author acknowledges Dr TAT Abdullah of the Centre of Hydrogen Energy and Institute of Future Energy at the Faculty of Engineering of Universiti Teknologi Malaysia (UTM) for the assistance with the TGA tests. The contribution of the University-Industry Laboratory of UTM is also gratefully acknowledged. 


\section{References}

Agroskin, A., Ei, G. and Gryaznov, N. (1972). Thermal Properties of Coals in Plastic State. Coke \& Chemistry, 1(9), 3-5.

Akinyemi, S. A., Adebayo, O. F., Nyakuma, B. B., Adegoke, A. K., Aturamu, O. A., Olaolorun, O. A., Adetunji, A., Hower, J. C., Hood, M. M. and Jauro, A. (2020a). Petrology, Physicochemical and Thermal Analyses of Selected Cretaceous Coals from the Benue Trough Basin in Nigeria. International Journal of Coal Science \& Technology, 7(1), 2642.

Akinyemi, S. A., Nyakuma, B. B., Adebayo, O. F., Kayode, A. T., Jauro, A., Olaolorun, O. A., Aturamu, A. O., Madukwe, H. Y., Adegoke, A. K., Abdullah, T. a. T., Gitari, W. M., Mudzielwana, R., Rabha, S., Saikia, B. K. and Hower, J. C. (2021). Geochemistry, Mineralogy and Thermal Analyses of Cretaceous Coals from the Benue Trough Basin Nigeria: Reconnaissance Assessments. Journal of African Earth Sciences, 178, 104167.

Akinyemi, S. A., Nyakuma, B. B., Jauro, A., Adebayo, O. F., Olaolorun, O. A., Adegoke, A. K., Aturamu, A. O., Adetunji, A., Gitari, W. M. and Mudzielwana, R. (2020b). Mineralogy, Physicochemical and Oxidative Thermal Analyses of Cretaceous Coals from the Benue Trough, Nigeria. Energy Geoscience, 1-7.

Ayinla, H. A., Abdullah, W. H., Makeen, Y. M., Abubakar, M., Jauro, A., Yandoka, B. M. S. and Abidin, N. S. Z. (2017a). Petrographic and Geochemical Characterization of the Upper Cretaceous Coal and Mudstones of Gombe Formation, Gongola Sub-Basin, Northern Benue Trough Nigeria: Implication for Organic Matter Preservation, Paleodepositional Environment and Tectonic Settings. International Journal of Coal Geology, 180, 67-82.

Ayinla, H. A., Abdullah, W. H., Makeen, Y. M., Abubakar, M., Jauro, A., Yandoka, B. M. S., Mustapha, K. A. and Abidin, N. S. Z. (2017b). Source Rock Characteristics, Depositional Setting and Hydrocarbon Generation Potential of Cretaceous Coals and Organic Rich Mudstones from Gombe Formation, Gongola Sub-Basin, Northern Benue Trough, Ne Nigeria. International Journal of Coal Geology, 173, 212-226.

Bi, Z., Li, K., Jiang, C., Zhang, J., Ma, S., Sun, M., Wang, Z. and Li, H. (2021). Performance and Transition Mechanism from Acidity to Basicity of Amphoteric Oxides (Al2o3 and B2o3) in Sio2-Cao-A12o3-B2o3 System: A Molecular Dynamics Study. Ceramics International, 47(9), 12252-12260. 
Blondeel, M., Van De Graaf, T. and Haesebrouck, T. (2020). Moving Beyond Coal: Exploring and Explaining the Powering Past Coal Alliance. Energy Research \& Social Science, 59, 101304.

Bortnikov, N., Novikov, V., Savko, A., Boeva, N., Zhegallo, E., Bushueva, E., Krainov, A. and Dmitriev, D. (2013). Structural-Morphological Features of Kaolinite from Clayey Rocks Subjected to Different Stages of Lithogenesis: Evidence from the Voronezh Anteclise. Lithology and Mineral Resources, 48(5), 384-397.

Chu, S. (2009). Carbon Capture and Sequestration. Science, 325(5948), 1599.

Chukwu, M., Folayan, C., Pam, G. and Obada, D. (2016). Characterization of Some Nigerian Coals for Power Generation. Journal of Combustion, 2016.

Hanrot, F., Ablitzer, D., Houzelot, J. and Dirand, M. (1994). Experimental Measurement of the True Specific Heat Capacity of Coal and Semicoke During Carbonization. Fuel, 73(2), 305-309.

Hayatsu, R., Botto, R. E., Scott, R. G., Mcbeth, R. L. and Winans, R. E. (1986). Evaluation of Lignin and Cellulose Contributions to Low-Rank Coal Formation by Alkaline Cupric Oxide Oxidation. Fuel, 65(6), 821-826.

Heinrichs, H. U., Schumann, D., Vögele, S., Biß, K. H., Shamon, H., Markewitz, P., Többen, J., Gillessen, B., Gotzens, F. and Ernst, A. (2017). Integrated Assessment of a Phase-out of Coal-Fired Power Plants in Germany. Energy, 126, 285-305.

Kajaste, R. and Hurme, M. (2016). Cement Industry Greenhouse Gas Emissions-Management Options and Abatement Cost. Journal of Cleaner Production, 112, 4041-4052.

Kim, D.-G., Konar, B. and Jung, I.-H. (2018). Thermodynamic Optimization of the K2o-A12o3Sio2 System. Ceramics International, 44(14), 16712-16724.

Košina, M. and Heppner, P. (1984). Macerals in Bituminous Coals and the Coking Process: Part 1: Effect of Basic Coal Properties on the Process of Thermal Degradation. Fuel, 63(6), 838-846.

Landais, P., Muller, J.-F., Michels, R., Oudin, J.-L. and Zaugg, P. (1989). Comparative Behaviour of Coal and Maceral Concentrates During Artificial Coalification. Fuel, 68(12), 16161619. 
Mccauley, D., Heffron, R., Pavlenko, M., Rehner, R. and Holmes, R. (2016). Energy Justice in the Arctic: Implications for Energy Infrastructural Development in the Arctic. Energy Research \& Social Science, 16, 141-146.

Mchugh, L. (2017). World Energy Needs: A Role for Coal in the Energy Mix.

Nyakuma, B. (2016). Physicochemical Characterization and Thermal Analysis of Newly Discovered Nigerian Coals. Bulgarian Chemical Communications, 48(4), 746 - 752.

Nyakuma, B., Jauro, A., Oladokun, O., Bello, A., Alkali, H., Modibo, M. and Abba, M. (2018). Physicochemical, Mineralogical, and Thermogravimetric Properties of Newly Discovered Nigerian Coals. Petroleum \& Coal, 60(4), 641-649.

Nyakuma, B., Jauro, A., Oladokun, O., Uthman, H. and Abdullah, T. (2016). Combustion Kinetics of Shankodi-Jangwa Coal. Journal of Physical Science, 27(3), 1-12.

Nyakuma, B., Oladokun, O., Akinyemi, S., Ojoko, E., Jacob, G., Abdullah, T., Alkali, H. and AlShatri, A. (2019). Comprehensive Evaluation of the Combustion Kinetic Characteristics of Owukpa Coal. Coke \& Chemistry, 62(8), 371-378.

Nyakuma, B. B. (2015). Physicochemical Characterization of Low-Rank Nigerian Coals. arXiv preprint arXiv:1506.02068.

Nyakuma, B. B. (2019). Physicochemical, Geomineralogical, and Evolved Gas Analyses of Newly Discovered Nigerian Lignite Coals. Coke \& Chemistry, 62(9), 394-401.

Nyakuma, B. B. and Jauro, A. (2016a). Chemical and Pyrolytic Thermogravimetric Characterization of Nigerian Bituminous Coals. GeoScience Engineering, 62(3), 1-5.

Nyakuma, B. B. and Jauro, A. (2016b). Physicochemical Characterization and Thermal Decomposition of Garin Maiganga Coal. GeoScience Engineering, 62(3), 6-11.

Nyakuma, B. B., Jauro, A., Akinyemi, S. A., Faizal, H. M., Nasirudeen, M. B., Fuad, M. a. H. M. and Oladokun, O. (2020). Pyrolysis and Combustion Characteristics of Newly Discovered Coals from Nigeria: Physicochemical, Microstructure, Mineralogy, and Thermal Properties. Research Square.

Nyakuma, B. B., Jauro, A., Akinyemi, S. A., Faizal, H. M., Nasirudeen, M. B., Fuad, M. a. H. M. and Oladokun, O. (2021). Physicochemical, Mineralogy, and Thermo-Kinetic Characterisation of Newly Discovered Nigerian Coals under Pyrolysis and Combustion Conditions. International Journal of Coal Science \& Technology. 
Nyakuma, B. B., Oladokun, O., Jauro, A. and Nyakuma, D. D. (2017). Fuel Characterization of Newly Discovered Nigerian Coals. IOP Conference Series: Materials Science and Engineering, 217(1), 012012.

Oecd Working Paper (2012). The Global Value of Coal IEA Coal Industry Advisory Board OECD, Paris.

Ogala, J. (2011). Source Rock Potential and Thermal Maturity of the Tertiary Lignite Series in the Ogwashi-Asaba Formation, Southern Nigeria. Asian Journal of Earth Sciences, 4(3), 157.

Ogala, J. E. (2012). The Geochemistry of Lignite from the Neogene Ogwashi-Asaba Formation, Niger Delta Basin, Southern Nigeria. Earth Sciences Research Journal, 16(2), 151-164.

Ogala, J. E. (2018). Geochemistry of Coal and Coal Bearing Strata from the Upper Cretaceous Mamu Formation, Southeastern Nigeria: Implications for Paleoredox History. FUW Trends Science Technology Journal, 3(2B), 787-796.

Ogala, J. E., Siavalas, G. and Christanis, K. (2012). Coal Petrography, Mineralogy and Geochemistry of Lignite Samples from the Ogwashi-Asaba Formation, Nigeria. Journal of African Earth Sciences, 66, 35-45.

Ohimain, E. I. (2014). Can Nigeria Generate 30\% of Her Electricity from Coal? International Journal of Energy and Power Engineering, 3(1), 28-37.

Pearson, B. (2014). The Battle over Cheap Energy in the Third World. Institute of Public Affairs Review: A Quarterly Review of Politics and Public Affairs, The, 66(1), 28-31.

Rafique, M. M. and Rehman, S. (2017). National Energy Scenario of Pakistan-Current Status, Future Alternatives, and Institutional Infrastructure: An Overview. Renewable and Sustainable Energy Reviews, 69, 156-167.

Reddy, P. J. (2013). Clean Coal Technologies for Power Generation. CRC press.

Sambo, A. (Year) Published. Prospect of Coal for Power Generation in Nigeria. A paper presented at the International Workshop for the Promotion of Coal for Power Generation, 2009. 2728.

Sarwar, A., Khan, M. and Azhar, K. (2014). The Physicochemical Characterization of a Newly Explored Thar Coal Resource. Energy Sources, Part A: Recovery, Utilization, and Environmental Effects, 36(5), 525-536.

Sengupta, P., Saikia, P. C. and Borthakur, P. C. (2008). Sem-Edx Characterization of an Iron-Rich Kaolinite Clay. Journal of Scientific and Research, 67(1), 812-818. 
Sonibare, O., Ehinola, O., Egashira, R. and Keangiap, L. (2005). An Investigation into the Thermal Decomposition of Nigerian Coal. Journal of Applied Sciences, 5(1), 104-107.

Speight, J. G. (2012). The Chemistry and Technology of Coal. (Third Edition ed). USA, CRC Press.

Sun, Q.-L., Li, W., Chen, H.-K. and Li, B.-Q. (2003). Tg-Ms Study on Pyrolysis Behavior of Shenmu Coal Macerals. Journal of China University of Mining \& Technology, 32(6), 664669.

Teh, S. H., Wiedmann, T., Castel, A. and De Burgh, J. (2017). Hybrid Life Cycle Assessment of Greenhouse Gas Emissions from Cement, Concrete and Geopolymer Concrete in Australia. Journal of Cleaner Production, 152, 312-320.

Wu, Z., Yang, W., Chen, L., Meng, H., Zhao, J. and Wang, S. (2017). Morphology and Microstructure of Co-Pyrolysis Char from Bituminous Coal Blended with Lignocellulosic Biomass: Effects of Cellulose, Hemicellulose and Lignin. Applied Thermal Engineering, 116, 24-32.

Xie, W., Stanger, R., Lucas, J., Wall, T. and Mahoney, M. (2013). Coal Macerals Separation by Reflux Classification and Thermo-Swelling Analysis Based on the Computer-Aided Thermal Analysis. Fuel, 103, 1023-1031.

Zhao, Y., Hu, H., Jin, L., He, X. and Wu, B. (2011). Pyrolysis Behavior of Vitrinite and Inertinite from Chinese Pingshuo Coal by TG-MS and in a Fixed Bed Reactor. Fuel Processing Technology, 92(4), 780-786. 